ing the view that a part of the variation of the cosmic ray intensity at ground-level may be explained by spontaneous disintegration of mesons in the atmosphere.

The increase of the correlation with height does not imply, of course, that mesons are formed at the layer of $75 \mathrm{~mm}$. pressure. They may be generated at higher layers, as suggested by the experiment of Schein, Jesse and Wollan ${ }^{2}$; but we can substitute for $\mathrm{H}-\mathrm{H}_{m}$ in the equation the fluctuations in height corresponding to $75 \mathrm{~mm}$. pressure and thus obtain a first approximation to the regression coefficients. By so doing, and by applying the method of least squares, we obtain for the coefficient of true absorption :

$\mu=2 \cdot 28$ per cent per cm. mercury, or $1.68 \times 10^{-3}$ em. ${ }^{2} / \mathrm{gm}$.

Ehmert $^{3}$ has measured the absorption curve in water and shown that the absorption coefficient down to a depth of $45 \mathrm{~m}$. is given by the formula $\mu=1 \cdot 56 / \mathrm{h}$, where $h$ is the depth in $\mathrm{gm}$./ $\mathrm{cm}^{2}$ On the other hand, from the theoretical results obtained by Rossi and Greisen ${ }^{4}$ for the range of mesons in air, iron and lead, we have estimated that the ratio of the range in water to that in air would be about 0.9 for mesons of energy not greater than $10^{9} \mathrm{eV}$. Assuming that Ehmert's formula is valid for air, and by applying the latter ratio to obtain the mass of water equivalent to the mass of air (thickness of the roof and counterbox included) above our apparatus, we obtain $\mu=1.65 \times 10^{-3} \mathrm{~cm} .{ }^{2} / \mathrm{gm}$., which is nearly the same as that obtained from our observations.

For the second regression coefficient or mean rate of decay of the meson we obtain

$\mu^{\prime}=0.054$ per $\mathrm{km}$., or $0.94 \times 10^{-3} \mathrm{em} .{ }^{2} / \mathrm{gm}$.

Kolhörster and Matthes ${ }^{5}$, by registering double coincidences while compensating for the variation of atmospheric pressure with a variable wood screen, have found for $\mu^{\prime}$ the value $1.15 \times 10^{-3} \mathrm{~cm} .2 / \mathrm{gm}$., which is of the same order. Taking into account, however, that no absorbers are used in our arrangement, allowance should be made for the amount of soft component which is recorded by the apparatus, and therefore the actual value of $\mu^{\prime}$ should be greater.

For the mean range of the meson before disintegration, we have

$$
L=\frac{1}{\mu^{\prime}}=18 \cdot 6 \mathrm{~km} \text {. }
$$

The mean life when at rest of a meson of $3 \times 10^{\circ} \mathrm{eV}$. energy would be $\tau_{0}=1.6 \times 10^{-6}$ sec.

As to the temperature effect $\alpha$, its value can also be obtained immediately by making use of Blackett's expression $^{6} \quad \alpha=-\delta z / L \delta \theta$. From meteorological data, $\delta z / \delta \theta=0.065 \mathrm{~km}$., for $z=16 \mathrm{~km}$.; hence

$$
\alpha=-0.35 \text { per cent per }{ }^{\circ} \mathrm{C} \text {. }
$$

This value is greater than that generally found, but this was to be expected since $\alpha$ has been usually referred to the temperature near the ground.

At the Department of Physics, A. DUPERIER. Imperial College of Science and Technology, London, S.W.7.

2 Duperier, NATURE, 149, 579 (1942).

Schein, Jesse and Wollan, Phys. Rev., 59, 615 (1941).

'Ehmert, Z. Phys., 106, 751 (1937).

- Rossi and Greísen, Rev. Mod. Phys., 13, 240 (1941).

5 Kolhörster and Matthes, Physik. Z., 40, 142 (1939).

- Blackett, Phys. Rev., 54, 973 (1938).

\section{Roozeboom's Type II of Solid Solution}

ON p. 20 of Jänecke's "Kurzgefasstes Handbuch aller Legierungen" (Leipzig: Spamer, 1937), there is the following statement: "Es wurde früher vielfach noch ein Typus vollständiger Isomorphie angenom. men, bei dem Schmelzpunkt-maximum auftreten sollte, obwohl hierfür niemals ein Beispiel gefunden war und auch schon von langen Jahren van Laar durch thermodynamische Betrachtungen nachgewiesen hatte, dass ein solcher Typus nicht auftreten könnte. Er wurde aber noch von Roozeboom angenommen, wodurch sich diese Auffassung noch in verschiedenen Lehrbüchern erhalten hat'.

Early in 1939, I wrote to Prof. Jänecke (to whom I am personally unknown), asking him how he accounted for the existence of an apparent confirmation of this type in the well-known system $d$ - and l-carvoxime (Adriani; Z. physikal. Chem., 33, 469; 1900). The following is Prof. Jänecke's reply, dated April 24, 1939. "Das bekannte System: $d$ - und $l$ Carvoxim und das neue: Malonsäure (-) monobornylester und $\mathbf{M}(+)$ ester ist kein Widerspruch mit dem von mir auf S.20 meines Buches gemachten Behauptungen. Es handelt sich in diesen Fällen ausgesprochenerweise um eine Verbindung, die beiderseits Mischkrystalle bildet. Es bilden sich entweder Mischkrystalle von $(d-l)$ mit $d$ oder mit $l$. Die Darstellung zerlegt sich in zwei Teile. Vermutlich wurden sich bei organischen optisch aktiven $n^{\mathrm{s}}$ Stoffen noch mehr Beispiele finden. Anderseits wird sich der Fall auf diese [word undecipherable] Verbindungen beschränken. In dem Nachtrag zu meinem Buche der Ende dieses Jahres erscheinen soll, werde ich hierauf noch kurz eingehen".

The reference to van Laar appears to be $Z$. physikal. Chem., 63, 216-253 (1908), the crux of the matter occurring on pp. 235-236. Van Laar deduces the inequality :

$$
\left(\alpha_{2}-\alpha_{2}{ }^{\prime}\right)<q_{2} \cdot \frac{T_{1}-T_{2}}{T_{2}}
$$

as the determining condition for a falling equilibrium temperature. $\quad T_{1}$ and $T_{2}$ are the absolute melting points of the pure components, $T_{1}$ being the higher : $q_{2}$ is the heat of fusion of the lower melting component: $\alpha_{2}$ and $\alpha_{2}^{\prime}$ are constants determining the differential heats of mixing of the low melting component in the liquid and solid phases respectively. From here on I use van Laar's own words: "Ist nun $T_{1}>T_{2}$ so ist das zweite Glied dieser Ungleichung immer positiv. Das erste Glied wird jedoch stets negativ sein, da die Grösse $\alpha_{2}^{\prime}$ (welche die Mischungswärme in der festen Phase bedingt) in allen normalen Fällen $>\alpha_{2}$ in der flüssigen Phase ist. Die obige Ungleichung wird somit sicherlich stets erfüllt sein, so dass die Schmelzcurve wohl niemals bei der höchsten Schmelztemperatur zu steigen anfängt, und ein Maximum folglich so gut wie ausgeschlossen ist." I add that van Laar's demonstration is not, like many of the demonstrations of the Dutch school, dependent on van der Waals' theories of state.

The matter is of some importance, since many text-books of physical chemistry, including one with which I am myself associated, includes the erroneous diagram.

Department of Chemistry, A. N. Campbell. University of Manitoba. 